\title{
Living Folklore: Unlimited Creativity
}

\author{
H N Hidayat ${ }^{1}$, Wasana ${ }^{2}$, Pramono $^{3}$, Sabar $^{4}$, P Husodo $^{5}$ \\ Universitas Andalas \\ \{herrynh@hum.unand.ac.id¹, wasana@hum.unand.ac.id², pramono@hum.unand.ac.id ${ }^{3}$, \\ purwohusodo@hum.unand.ac.id $\left.{ }^{4}\right\}$
}

\begin{abstract}
This paper describes the form of folklore transformation. Folklore, which is identic with orality, transformed in several forms of modern media so that it is more accessible and familiar with the current generation. In its new form, folklore is considered to be able to surpass its era. On the other hand, there have been many theories and studies on folklore. Aesthetics, literature, textual, contextual, historical, geographic, and anthropological are fields of science commonly used for folklore studies. However, all has not yet been able to answer the question, is there a novelty in folklore and folkloristics as a scientific discipline? Folklore has shown astounding growth involving digital devices. Under the folkloristic computation, geographical and historical methods seem to be reliable navigation technology in the folklore development. Folklore in the digital age is a complex and sometimes confusing arrangement of expressions. However, in this digital era, several varieties of folklore
\end{abstract}

Keywords: Folklore, Transformation, Internet, Oral, Digital

\section{INTRODUCTION}

Until now, especially in Indonesia, folklore was considered as "something" that was ancient, classic, and not interesting to talk about. In addition, many researchers consider research on folklore is difficult. This is due to one characteristic of oral folklore [1]. Another thing that reinforces this assumption, folklore study is a field that collects data from owners and users.

As objects of social humanities research, folklore is dynamic and changing rapidly. The development and expansion of verbal folklore made folklore have an unlimited variant tendency [1]. Folklore is studied informally, knowledge of the world, personal, community, beliefs, culture and traditions are creatively expressed through words, music, customs, actions, behavior and other material. Folklore is also an interactive process, creative process, communication, and performance shared by the owner and user [2]. Therefore, every time it is said, folklore has the possibility of changing, both increasing and decreasing the content. This is also what raises the question of scientific research on folklore.

Apart from the earlier discussion, folklore has been agreed as intangible intellectual property that reflects a community group. Through the form and content of folklore, someone can indirectly get an idea of the identity of the community or group of owners of the folklore [3]. The legend "Malin Kundang" for example, indirectly describes a group of a coastal community because of the contents of the story display beaches, seas, and ships [4]. On the 
contrary, the story of "Jaka Tarub" does not reflect coastal communities because the story shows forests, rivers, lakes, and mountains [5].

This nature of folklore has finally become one of the backgrounds of the stereotypical impression of a community. These stereotypes develop because they are used repeatedly and admitted upon by the community, although it is in contrast to reality. For example, Javanese stereotypes who are meek and prefer to succumb on conflict [6], Madurese who are considered stubborn [7], Minangkabau people are considered stingy and resourceful [8], and others. As with folklore, the community of users is no longer convinced that the stereotype is true or not.

As is well known, folklore in Indonesia has various forms and varieties. Furthermore Dananjadja [1] states, folklore is divided into oral, half-oral and non-verbal folklore. Legends, myths, superstitions, puzzles, anecdotes, folklore, culinary, even architectural are some of the variations. Therefore, folklore is not only about myths, legends, or folklore for reasons of oral form, but also aspects of orality are important in his conversation.

The oral aspect can be considered as one of the limitations of folklore. The range of distribution and designation is limited to space and time. Superstitions, legends, traditional culinary, and myths in the end only known and trusted by the people who owned them. Palasik, for example, is only known by Minangkabau people[9]-[11], leak in Bali, or wewe gombel in Java [12], [13]. On the other hand, traditional culinary as a variety of non-verbal folklore also represent the distinctiveness of a community. According to Wurianto [14], traditional culinary conceptualized as an illustration of the complexity of people's life patterns that is able to present the identity of collectivity and social-cultural representation based on good food in conceptualizing food, social functions of food, how to obtain food, how to process food and how to present food. Thus there is a link between socio-cultural identity, socio-cultural representation, consumption patterns, and production and the existence of a regulatory background in agreeing on cultural products in the form of traditional culinary.

In addition, folklore is also geographical. Traditional communities in certain regions have a different picture of something despite the same shape or nature. For example, the image of a dragon in Asia is very different from that in Europe and America. Dragons in Asia are portrayed in the form of snakes and have a tendency to be good [15], while in Europe and America they are described as being lizards with a tendency towards evil [16].

That geographical characteristics can be one reason that folklore is also used as a tool to legitimize a particular society. Many tribes have myths as proof that they are descendants of gods or goddesses [17]. There are also many societies of people who describe them as descendants of humans with magical powers or born with superpowers. For example, the emergence of the myth of "Nyi Roro Kidul" in Yogyakarta is considered a tool of legitimacy at the time of the Mataram Kingdom [18]. In other words, folklores are actually the imagination of a community to legitimize theirs.

However, the limitations of the nature of folklore are no longer valid because of the current advances in information technology. Folklore is no longer limited to space and time, usage, distribution, and even users. Folklore has transformed and even evolved into a more globally acceptable form through cyberspace, the internet.

\subsection{Reserch Method}

Tradition has always been the main term in the definition of folklore. The tradition here is defined relative to the culture in which it grows. However, what is common to all known definitions is its dialogical and dialectical relationship with modernity [19]. In this case, tradition can be defined in two categories, tradition as a process and tradition as a resource. As 
a process, tradition shows activity or effort reaching the future and is temporal. As a resource, tradition is very broad and unlimited. In this sense, the tradition will always develop because of its flexible nature. Therefore, tradition has the possibility of variation and innovation [20].

In general, folklore involves communication through games, songs, stories, anecdotes, and other traditional activities from one individual to another, and from one generation to the next. Every folklore has distinctiveness, always dynamic, and reflects the wants, needs, and values of a society [21].

In Indonesia particularly, besides being identified with folk prose stories, folklore is also commonly associated with oral traditions with inheritance carried out from generation to generation. However, folklore is a broader term than just stories or traditions. Folklore reaches out to groups of people who share personal matters of trust as part of the group.

Alan Dundes explains the structural concept in folkloristics as a study of organizational relations between elements in folklore. This concept is taken from the structuralism concept in linguistics, which arises from within the system or generative structure. Nevertheless, Dundes added, structuralism in folklore contained human philosophical implications, namely creativity [22]. Therefore, studying folklore is the same as studying the transformation of individuals and groups. Understanding folklore is one way to understand a community group [2], [23].

Folklore is a social product that lives, grows, and develops in the dynamics of a particular society. Through folklore, a society can interact and communicate in full context of agreed symbols. Noyes [24] expressly states that in a group, humans are connected through folklore, not in an abstract form, but in form and representation that can be traced empirically. Folklore can be considered as group identity, but it is more often known as a symbol of cultural bonding.

For example, a wedding ceremony. As one of the human stage life, marriage has been considered a sacred activity. In Indonesia generally, marriages are carried out according to the customs or traditions. Some regions even demand something that is difficult to accept for the present. In the tradition of "kawin colong" in the Osing society in Banyuwangi, a man must steal (kidnap) a prospective wife without the knowledge of her parents [25]. In the context of law, this tradition is illegal. However, as a tradition, the procession was natural and accepted by the local community. This shows the local wisdom of the Osing community in answering problems that arise in their situation which is as an alternative solution when a man is hindered from marrying a girl for reasons the girl's parents' consent.

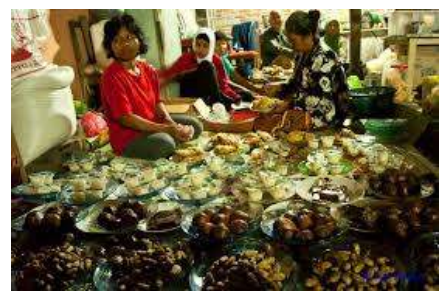

Figure 1. Social relations in a traditional wedding.

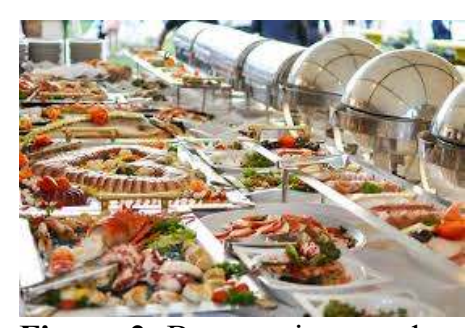

Figure 2. Banquet in a modern wedding.

On the other hand, wedding ceremonies have now become a business. Marriage is no longer carried out at home but in meetinghouses or hotels [26] even broadcast live on television [27]. The tradition has changed into a formality ceremony. The meaning and philosophy in this traditional activity become faded. People who gather together to manage and organize a wedding ceremony are no longer the main requirements of the marriage ritual. 
However, this is in accordance with the nature of tradition that dynamically follows social developments. Wedding ceremonies in meetinghouses or hotels that tend to trim elements of this tradition are the answer to the anxiety of the people who own. Tradition is considered too complex and requires many activities which of course involve many people [28], [29]. By giving up the management of the wedding ceremony to another party, someone will feel lightened. The social ties contained in folklore eventually change by themselves which of course in different social contexts (members, interests, geographies, etc.) [30].

\subsection{Result and Discussion}

The development of folklore cannot be separated from the globalization era. Perspective and acceptance of folklore also changed. The rapid advancement of technology as one of the globalization characteristics has contributed to these changes. However, globalization should not be interpreted as similarity or equality. In this case, folklore still has its own characteristics even though it has filtered space and time. Folk and lore as the main elements of folklore can still be known and identified.

In growing and developing, folklore is encouraged to find its formulation independently so that it changes even though it is controlled by owner society [31]. Folklore has a farther range than it seems. For example, although it can be said to be persistent, oral stories have migrated to literature and scientific fields, and have permeated the process of contemporary thought. In this sense, tradition (folklore) is an ongoing process that can reach the future [32].

At present, folklore is no longer considered to refer to tribal or national identity, regardless of certain political interests, and is used to strengthen a group's particular power [33]. Zhang [34] states that what is important to note at this time is how folklore forms group identity in the modern world, especially in the era of globalization. In addition, Conrad [35] adds that despite having a collective cultural aspect, folklore is temporary and continually shapes and keeps away from the practice of the textual interpretation of the community. This is evidenced by the emergence of "new folklore" forms which are currently still considered "not folklore".

Apart from narrative, symbolic, mythical, or ritual forms, one part that often escapes folkloristic attention is work (job). A job is a human activity that links tradition with improvisation which ultimately forms and builds a culture [19]. Almost every job has its own folklore. A teacher is identical to a good example, a trader is identical to his provocative conversation, or a truck driver who is identical to playing with women and rarely back home.

Interestingly, this type of folklore can also be called a profession stereotype and tends to be a joke or anecdote that formulates new folklore. There are folklore varieties in writing and drawing on the back of the truck or on public transportation. The contents are not far from something related to the job, drivers. 


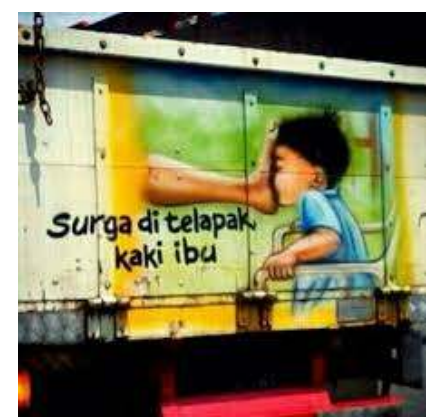

Figure 3. Heaven is on mother's feet

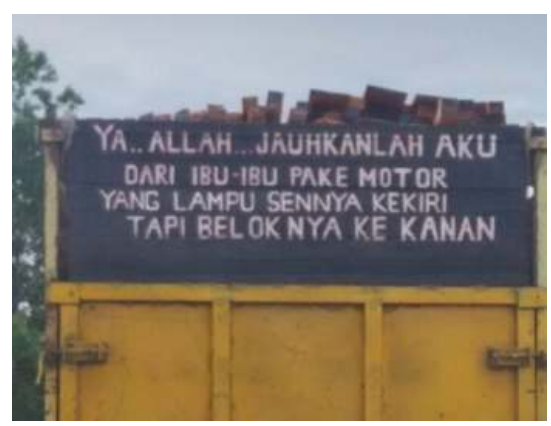

Figure 4. Driver's prayer

Social status has also built and formed its own folklore. There has been a judgment in the community that being single is an embarrassing condition and low self-esteem. Like the driver, singles have created folklore form independently.

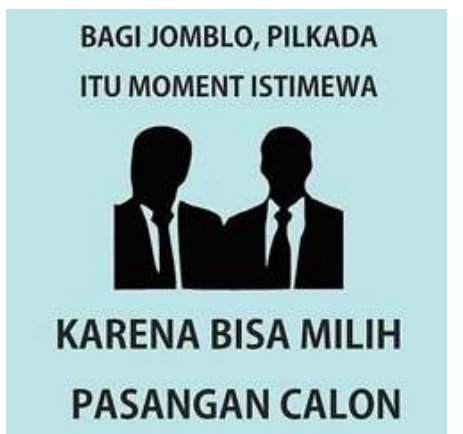

Figure 5. Singles and election

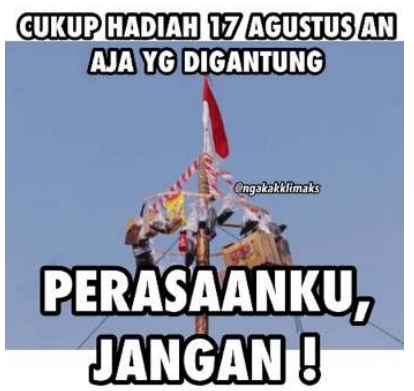

Figure 6. Single and

Independence day celebrations

Figure 3 - 6 shows the factors of creativity in the development of folklore. Assumptions about a profession are processed and restated in new forms and through new media. The classic proverb, surga di telapak kaki ibu 'heaven is on mother's feet', which was previously considered sacred was created and displayed in a different form as a parody. Of course, the meaning doesn't just disappear. The content of advice still feels even in a different view (Figure 3). On the other hand, the figure of a mother who is duly respected, on the streets is considered a figure that must be avoided. This happens because of the assumption that middleaged women, "emak-emak", always careless on the road without caring about others (Figure 4).

Through digital media, the internet, folklore grows and develops as if unlimited. Creativity is an important key on this. Internet users in the age category are also driving for the folklore dynamics in this media. Gillis [36] states that media interference not only accelerates but also enlarges and broadens the growth of folklore. The internet not only helps dissemination and introduction of folklore.

Figures 5 and 6 are examples of images that appear from one account on Instagram. The speech and pattern of the communication show the users as folk. Each follower will understand the symbols that appear in each picture. The analogy and association of the text- 
context of words jomblo, elections, August 17, panjat pinang image, hanging gifts, and feelings, are easily understood by the followers. This is certainly based on the same knowledge and expectations when the followers read (see).

Folklore has shown astounding growth involving digital devices. Under the folkloristic computation, geographical and historical methods seem to be reliable navigation technology in the folklore development [37]. Besides information purposes, the internet is also used as a tool for transferring ideas, opinions, and arguments. This type of social reaction builds on a variety of new folklores-whether oral, written, or visual - that is global, e-folklore [38]. Folk processes the transmission of each society member so that variations continue constantly even they occur in the unexpected media. In this case, every human being is folk, all humans are folk, although sometimes they are still influenced by traditional expression patterns [39]. In the digital world, folk has been identified in the form of chat forums, blogs, vlogs, social media, or web pages. New traditions have been formed in online communities [40].

Folklore in the digital age is a complex and sometimes confusing arrangement of expressions. However, in this digital era, several varieties of folklore (such as songs, stories, puns, visual humor, etc.) develop but not in a permanent form. To be sure, most of these folklores are mediated by modern technology and show repetition and variation only to disappear after a short period of circulation [40], [41] [42].

\section{CONCLUSIONS}

Technology, as a modern product, does not intend to separate, eliminate, or destroy past products. Technology by itself will create a new way to establish relationships between the two that sometimes have unexpected impacts [40]. In the traditional context, folklore is only owned and understood by one particular group. But using technological devices, folklore can be known more widely and globally. Before the internet, the spread of the "om telolet om" phenomenon globally was unreasonable.

Through this information technology, a variety of digital-based folklores emerged. Internet users may not know J Pop, K Pop, cosplay, anime and so on. In this digital era, both folk and lore have found their way to grow, develop, transform, and even evolve following changes in the social context both materially and formally.

\section{ACKNOWLEDGEMENTS}

The author expresses gratitude to Lembaga Penelitian dan Pengabdian kepada Masyarakat Universitas Andalas, Program Studi Sastra Minangkabau Universitas Andalas, and Asosiasi Dosen Pendidikan Bahasa Indonesia.

\section{REFERENCES}

[1] J. Danandjaja, Folklor Indonesia: Ilmu Gosip, Dongeng, dan Lain Lain. Jakarta: Pustaka Grafitipress, 2002.

[2] M. C. Sims and M. Stephens, Living Folklore: An Introduction to the Study of People and Their Traditions, 2nd ed. Utah: Utah State University Press, 2005.

[3] A. B. Muslim, N. Nafisah, and I. L. Damayanti, "LOCALITY AND SELF-IDENTITY: Local story inclusion in Indonesian English Text Books," in School of Language Studies 
and Linguistics International Conference, 2009.

[4] U. Junus, "Malin Kundang dan Dunia Kini," Sari, vol. 19, pp. 69-83, 2001.

[5] P. G. Yanti and F. Zabadi, "A Comparative Study of Indonesian Fairy Tales Structure," Artic. Rupkatha J. Interdiscip. Stud. Humanit., vol. VIII, no. 3, 2016.

[6] H. Wijayanti and F. Nurwianti, "KEKUATAN KARAKTER DAN KEBAHAGIAAN PADA SUKU JAWA," J. Ilm. Psikol., vol. 3, no. 2, Feb. 2011.

[7] T. Rochana, "ORANG MADURA: SUATU TINJAUAN ANTROPOLOGIS," Humanus, vol. 11, no. 1, p. 46, 2012.

[8] Y. P. W. Suseno, "PENGGAMBARAN IDENTITAS ETNIS MINANG DALAM FILM TABULA RASA," Universitas Airlangga, 2016.

[9] N. Cecioria, "UNSUR-UNSUR MAGIS DALAM LIRIK LAGU MINANGKABAU," WACANA Etn., vol. 2, no. 2, pp. 96-116, Oct. 2011.

[10] H. Nelwatri, "KESEHATAN REPRODUKSI PADA ETNIS MINANGKABAU," Kafa ah J. Gend. Stud., vol. 4, no. 1, p. 71, Jan. 2014.

[11] H. WS, "KEARIFAN LOKAL DALAM TRADISI LISAN KEPERCAYAAN RAKYAT UNGKAPAN LARANGAN TENTANG KEHAMILAN, MASA BAYI, DAN KANAKKANAK MASYARAKAT MINANGKABAU WILAYAH ADAT LUHAK NAN TIGO,” KEMBARA J. Keilmuan Bahasa, Sastra, dan Pengajarannya, vol. 1, no. 2, pp. 198-204, Oct. 2015.

[12] T. A. Maheswarina, "KEPERCAYAAN MASYARAKAT JAWA DALAM FILM KUNTILANAK," Malang, 2012.

[13] Sugihastuti, "FUNGSI MITOS SEBAGAI MEDIA PENDIDIKAN KARAKTER: STUDI MITOS KOLONG WEWE," in Seminar Nasional Sastra, Pendidikan Karakter, dan Industri Kreatif, 2015, pp. 243-258.

[14] A. B. Wurianto, "Aspek Budaya pada Tradisi Kuliner Tradisional di Kota Malang sebagai Identitas Sosial Budaya (Sebuah Tinjauan Folklore)," Malang, 2008.

[15] L. N. Hayes, The Chinese Dragon. Shanghai: Commercial Press, 1923.

[16] J. F. F. Campbell, The Celtic Dragon Myth. Edinburg: John Grant, 1911.

[17] Ō. Taryō, "Japanese Myths of Descent from Heaven and Their Korean Parallels," Asian Folkl. Stud., vol. 43, no. 2, pp. 171-184, 1984.

[18] R. Wessing, "A Princess from Sunda: Some Aspects of Nyai Roro Kidul," Asian Folkl. Stud., vol. 56, no. 2, p. 317, 1997.

[19] R. F. Bendix and G. Hasan-Rokem, "Concept and Phenomenon," in A Companion to Folklore, R. F. Bendix and G. Hasan-Rokem, Eds. West Sussex: Wiley - Blackwell, 2012.

[20] R. Cashman, T. Mould, and P. Shukla, Eds., The Individual and Tradition: Folkloristic Perspectives. Bloomington and Indianapolis: Indiana University Press, 2011.

[21] E. Tucker, Children's Folklore. Westport Connecticut Londoon: Greenwood Press, 2008.

[22] S. J. Bronner, "Folk Logic: Interpretation and Explanation in Folkloristics," West. Folk., vol. 65 , no. 4, pp. 401-433, 2006.

[23] H. N. Hidayat and Wasana, "Melampaui Kata: Transformasi Folklore," in Khazanah Melayu Serumpun dalam Era Baharu, 2018, no. November.

[24] D. Noyes, "The Social Base of Folklore," in A Companion to Folklore, R. F. Bendix and G. Hasan-Rokem, Eds. West Sussex: Wiley - Blackwell, 2012.

[25] R. Wagianto, "Tradisi Kawin Colong Pada Masyarakat Osing Banyuwangi Perspektif Sosiologi Hukum Islam," Al-Ahwal J. Huk. Kel. Islam, vol. 10, no. 1, p. 61, 2017.

[26] H. Adler and T. C. Chienm, "The Wedding Business," J. Foodserv. Bus. Res., vol. 7, no. 1, pp. 117-125, Feb. 2004. 
[27] R. Sgroi, “Consuming the Reality TV Wedding,” Ethnologies (Que),, vol. 28, no. 2, p. 113, 2006.

[28] H. T. Febriantiko, "PERBANDINGAN PROSESI PERKAWINAN ADAT KERATON YOGYAKARTA MASA SRI SULTAN HAMENGKUBUWONO VIII DAN IX," Avatara, vol. 2, no. 2, 2014.

[29] S. Priyadi, "Orientasi Nilai Budaya Banyumas: Antara Masyarakat Tradisional Dan Modern," J. Hum., vol. 20, no. 2, pp. 158-167, Aug. 2012.

[30] O. Goldstein-Gidoni, "The Production of Tradition and Culture in the Japanese Wedding Enterprise," Ethnos, vol. 65, no. 1, pp. 33-55, Jan. 2000.

[31] U. Marzolph, "What Is Folklore Good For? On Dealing with Undesirable Cultural Expression," J. Folk. Res., vol. 35, no. 1, p. 5, 1998.

[32] F. V. da Silva, "Tradition Without End," in A Companion to Folklore, R. F. Bendix and G. Hasan-Rokem, Eds. West Sussex: Wiley - Blackwell, 2012.

[33] S. O. Gencarella, "Constituting Folklore : A Case for Critical Folklore Studies," J. Am. Folk., vol. 122, no. 484, pp. 172-196, 2009.

[34] J. Zhang, "Folklore in China: Past, Present, and Challenges," Humanities, vol. 7, no. 35 , p. 20, 2018.

[35] J. Conrad, "The Storied Time of Folklore," West. Folk., vol. 73, no. 2/3, p. 323, 2014.

[36] B. Gillis, "An Unexpected Font of Folklore - Online Gaming as Occupational Lore," West. Folk., vol. 70, no. 2, pp. 147-170, 2011.

[37] J. D. Dorst, "Folklore's Cybernetic Imaginary, or, Unpacking the Obvious," J. Am. Folk., vol. 129, no. 512, pp. 127-145, 2016.

[38] V. Krawczyk-Wasilewska, "e-Folklore in the Age of Globalization," Fabula, vol. 47, no. 3/4, p. 248, 2006.

[39] J. H. Brunvand, "Folklore in the news (and on the net)," West. Folk., vol. 60, no. 1, pp. 47-66, 2001.

[40] T. J. Blank, Ed., Folklore and the Internet: Vernacular Expression in a Digital World. Utah: Utah State University Press, 2009.

[41] K. Saddhono and S. Supeni. "The role of dutch colonialism in the political life of Mataram dynasty: A case study of the manuscript of Babad Tanah Jawi." Asian Soc. Sci. vol. 10 no. 15 pp. 1-7, 2014

[41] T. Blank, "Folklore and the Internet: The Challenge of an Ephemeral Landscape," Humanities, vol. 7, no. 2, p. 50, 2018. 